EXPERIMENTS IN THE ARTIFICIAL PROPAGATION OF FRESH-WATER MUSSELS * * * *

From BULLETIN OF THE BUREAU OF FISHERIES, Volume XXVII, I908 Proceedings of the Fourlh International Fishery Congress : : Washington, 1908 

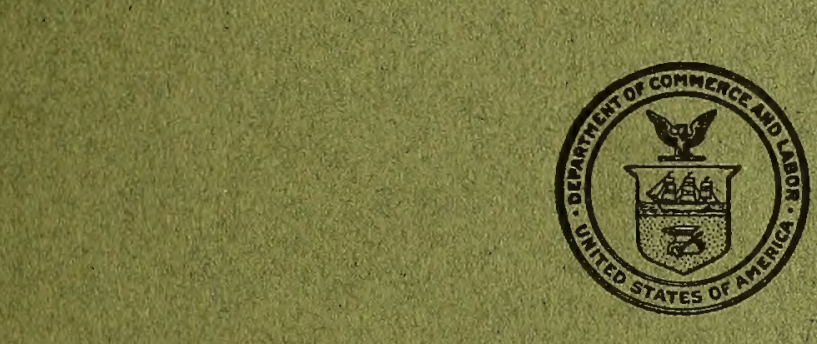

WASHINGTON : : : : : : GOVERNMENT PRINTING OFFICE : : : : ; : 1910 



\section{EXPERIMENTS IN THE ARTIFICIAL PROPAGATION OF FRESH-WATER MUSSELS * * * *}

From BULLETIN OF THE BUREAU OF FISHERIES, Volume XXVIII, I9o8

Proceedings of the Fourth International Fishery Congress : Washington, I908

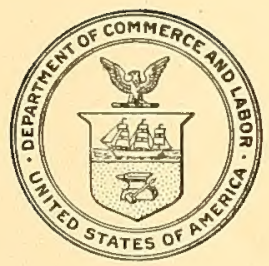

WASHINGTON $: \quad: \quad: \quad: \quad:$ GOVERNMENT PRINTING OFFICE $\quad: \quad: \quad: \quad: \quad: \quad 1910$ 


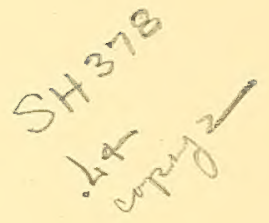

BUREAU OF FISHERIES, DOCUMENT NO. 671

Issued April, 1910

$$
\text { APR } 151910
$$

$\therefore$ 


\section{EXPERIMENTS IN THE ARTIFICIAL PROPAGATION}

OF FRESH-WATER MUSSELS

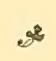

By George Lefevre and W. C. Curtis

Professors of Zoology, University of Missouri

*

Paper presented before the Fourth International Fishery Congress

held at Washington, U. S. A., September 22 to 26, 1908 


\section{CONTENTS.}

Object and scope of the undertaking

Some facts in the reproduction and life history of mussels _... 618

Breeding seasons . . . 620

The larva, or glochidium _... 62 I

Implantation of the glochidia _ . 622

Experimental infections. . 622

Method

Behavior of the fishes_Their susceptibility and resistance

Duration of the parasitic period. 624

Post-larval growth of mussels _...

Infection of large numbers of fish 616 


\title{
EXPERIMENTS IN THE ARTIFICIAL PROPAGATION OF FRESH-WATER MUSSELS.
}

\author{
\# \\ By GEORGE LEFEVRE and W. C. CURTIS, \\ Professors of Zoology, University of Missouri. \\ $\$$ \\ OBJECT AND SCOPE OF THE UNDERTAKING.
}

The threatened extinction in the Mississippi River and its more important tributaries of those species of mussels whose shells have been taken in enormous numbers during the past fifteen years for the manufacture of pearl buttons has led the United States Bureau of Fisheries to undertake an extensive investigation to determine the possibility of artificial propagation of these mollusks, and to devise such means as may be practicable for restocking depleted waters which present favorable conditions. The general direction of the investigation has been placed in the hands of the writers, who for the past three years have devoted to the work as much time as their professional duties would allow. In certain phases of the work, however, many others have collaborated.

It was recognized at the outset that if the investigation was to have real practical value it would have to be wide in scope and extend over a period of at least several years. At that time little was known with accuracy of the breeding habits and seasons of the commercial species, of the biological and physical conditions under which they live, of their distribution, and of many other essential matters, while it yet remained to be discovered whether artificial propagation could be successfully accomplished. At the very inception of the work, therefore, a comprehensive plan was outlined which was designed to include every subject that might bear even remotely upon the central problem, and, although many parts of this programme have not yet been touched, much progress has been made in some of the more important lines.

The plan of work contemplated, besides a thorough investigation of artificial propagation, a detailed study of the life history and ecology of the Unionidæ, emphasizing especially the geographical distribution of the group throughout the Mississippi Valley, the breeding habits and seasons, the physical conditions of the waters in which the different species thrive, food, enemies, and diseases, 
rate of growth, post-embryonic development, and the mutual behavior of glochidia, or larvæ, and fishes as parasites and hosts.

The results that have already been obtained, although far from being complete, will serve as a basis for future investigations, while the lines of attack in the main problems have been definitely indicated. We have proceeded far enough to make it clear that the ultimate end of the investigation is assured, and with proper facilities for the infection and care of large numbers of fish the final success of the work is no longer in doubt. The essential facts in the life history of the Unionidæ are known; the general conditions of infection have been determined; the entire feasibility of artificially infecting large numbers of fish has been established; while the requisite conditions for placing artificial propagation on a practical basis are clearly understood. Furthermore, during the summers of 1907 and 1908 several parties, working under the direction of the Bureau of Fisheries, have made extensive observations on a number of different rivers in the upper Mississippi Valley, with a view to determining the distribution of all of the species of mussels occurring in these waters. The rivers that have been explored in this manner are the upper Mississippi, Illinois, Iowa, Minnesota, Wabash, Ohio, and Tippecanoe, as well as several smaller streams in Indiana. When the results obtained by these parties have been brought together, we should be in possession of detailed information regarding the distribution and relative abundance of at least all of the important commercial species throughout this region. In addition, the breeding seasons of almost all of the important commercial species have been determined, and a large mass of miscellaneous data relating to a great variety of subjects has been accumulated.

Some of the more important results that have thus far been obtained in the investigations are briefly presented here.

\section{SOME FACTS IN THE REPRODUCTION AND LIFE HISTORY OF MUSSELS.}

As is well known, the Unionidæ carry their young in the gills, which act as a marsupium or brood chamber until the completion of the embryonic development. The eggs are passed from the ovaries into the suprabranchial chambers, where they are fertilized by spermatozoa brought in by the inhalent current of water. In many species the eggs are bound together in masses by a gelatinous or glutinous matrix which is secreted by the gills and which may be very tenacious. This, however, in most cases gradually dissolves away as development proceeds, until at the close of the embryonic period the larvæ or glochidia are no longer agglutinated. These masses assume in different species many forms of flat plates or cylindrical cords which fill the water tubes of the gills. The latter may be greatly distended or modified in various ways to receive the egg-masses. In some species, on the other hand, the condition 
just described is absent and the eggs are either not agglutinated at all or are only loosely held together in a slightly viscid substance.

The extent to which the gills are modified as a marsupium varies greatly in different genera. In many, as in Anodonta, Pleurobema, Strophitus, Symphynota, and Unio, the entire outer gill of each side is thus utilized and when filled with embryos or glochidia, presents a much swollen, padlike appearance. In others, for example, Lampsilis, Obovaria, Plagiola, only the posterior portion, varying from one-third to two-thirds of the entire outer gill, is used as a receptacle for the eggs, a sharp demarcation existing between the marsupial region and the anterior respiratory part. The former is highly modified in structure and may be readily recognized, even when empty. In Obliquaria reflexa a varying number of enlarged and distended water tubes contain the dense, glutinous cords in which the embryos are embedded. Finally, there are at least two genera, namely, Quadrula and Tritigonia, in which all four gills are utilized as brood chambers. This condition would seem to be the most primitive one, as the gills show but little structural modification and when empty are indistinguishable from those of the male mussel.

In all of the species of the genus Lampsitis which we have examined the posterior margin of the valves in the female is less pointed than in the male, and by reason of this difference in the shape of the shells the sexes may be readily distinguished externally. In most of the other genera that have come under our observation, however, the shells of the two sexes are identical, and an internal examination is necessary in order to determine the sex of an individual.

The entire embryonic development takes place within the marsupium, and at the end of this period the glochidium, which has become liberated from the egg membrane within the gill, is fully formed. In those species which are known as "summer breeders," the glochidia are discharged at once, while in many others, the so-called "winter breeders," they are carried in the gills for several months before being set free in the water.

The glochidia, as has long been known, do not complete their development unless they become attached to fishes, and the metamorphosis occurs while they are living parasitically in a cyst formed by the epidermis of the host. After discharge from the marsupium, the glochidia under natural conditions lie quiescent on the bottom, their valves gaping widely apart, and unless chance brings them in contact with a fish they will die. Once attached to the gills or external parts of a fish, however, the rest of the development, if conditions are favorable, is assured.

This unique peculiarity in the life history of fresh-water mussels has been taken advantage of in artificial propagation, as it has been found that a single fish, even though small, may successfully carry to the close of metamorphosis several hundred glochidia. One fish may, therefore, be made to do the work 
of a large number in a state of nature, for under ordinary conditions it is extremely improbable that more than a very few glochidia would succeed in attaching themselves to a single fish.

After a parasitic life of variable length, during which the metamorphosis is completed, the cyst breaks down, and the young mussel, thus liberated, falls to the bottom and leads thereafter an independent life.

\section{BREEDING SEASONS.}

We have confirmed the conclusion, first reached by Sterki (Nautilus, vol. IX, I895), that the Unionidæ, with respect to their breeding seasons, fall into two classes, the so-called "summer breeders" and "winter breeders." The latter designation, however, is not strictly appropriate, for in the species which belong to this group the eggs are fertilized during the latter part of the summer, usually in August, and the glochidia, which are carried in the brood chambers over the winter, are not discharged until the following spring and summer. In fact, in some cases the close of one breeding period may overlap on the beginning of the next, as one may still find in late July some females gravid with glochidia, while in others the eggs are passing into the gills for the next season. In the case of the summer breeders the eggs are fertilized during the late spring and summer, and the glochidia are in all probability discharged before the end of August, or certainly not later than the middle of September. In the species of this class of which we have the completest records, ovulation begins in May and early June and may last well into August, but after the end of August gravid females have not been found.

In view of the above facts, it would seem in better accord with actual conditions to separate the species with respect to the length of time that the glochidia remain in the gills, designating them as those which have a "short period" of gravidity and those having a "long period," rather than to distinguish them as "summer breeders" and "winter breeders," respectively, for in the case of the latter neither ovulation nor discharge of the glochidia takes place in winter. The breeding season is undoubtedly a generic character, for, so far as our observations go, all species of a given genus belong to the same class.

The following list shows the distribution, with respect to the period of gravidity, of the genera we have had under observation:

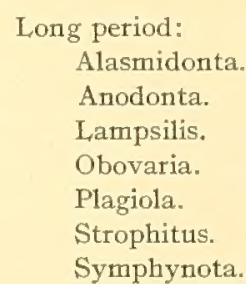

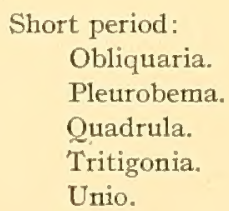


As there are important commercial species in each class, the futility of any law which would prohibit the taking of mussels during their breeding season becomes at once apparent, for there is no month in the year when some species are not carrying either embryos or glochidia.

THE LARVA, OR GLOCHIDIUM.

Two well-marked types of glochidia occur in the Unionidæ, one provided with stout hooks on the ventral margin of the valves and the other entirely hookless. The former are characteristically parasitic on the fins and other external parts of the fish, the latter on the gills. We have given special attention to a study of the physiological peculiarities correlated with these two types of structure, including their differences in behavior in attachment.

The occurrence of the two types of glochidia in the genera which we have examined is shown below.

$\begin{array}{ll}\text { Hookless glochidia: } & \text { Hooked glochidia: } \\ \text { Lampsilis (except L. lævissimus). } & \text { Anodonta. } \\ \text { Obliquaria. } & \text { Lampsilis lævissimus. } \\ \text { Obovaria. } & \text { Strophitus. } \\ \text { Plagiola. } & \text { Symphynota. } \\ \text { Pleurobema. } & \\ \text { Quadrula. } & \\ \text { Tritigonia. } & \\ \text { Unio. } & \end{array}$

It is thus seen that the hookless type is by far the commoner one, and furthermore, practically all of the commercial species of mussels belong to the genera included in this class.

The type of glochidium is constant for the genus, so far as our observations have gone, except in the genus Lampsilis, one species of which, L. levissimus, produces glochidia having hooks, while all of the remaining species that we have examined have the hookless forms. The glochidia of $L$. lavissimus, moreover, are of quite a different form from those of any other species we have encountered, being shaped like an axe head when seen in side view.

The hookless glochidia are usually much smaller than those having hooks, and also differ characteristically from the latter in shape.

We have repeatedly determined the fact that the hooked glochidia form permanent attachment as a rule only to external parts of the fish, as the margins of the fins, operculum, anus, and mouth, the barbules, or even to scales and along the fin rays occasionally. Wherever a free border is presented that may be grasped between the valves of the glochidium, attachment is possible, the hooks holding securely as soon as the valves have closed. Hooked glochidia, furthermore, are not infrequently found on the gill arches and rakers, as these places furnish the requisite conditions for a firm grasp. Glochidia of this type, 
however, do not as a rule acquire a permanent lodgment on the delicate gill filaments, as their hooks usually tear through these when grasping. Their greater size would also seem to render it difficult for the hooked glochidia to become properly embedded under the epidermis of the slender filament.

Hookless glochidia, on the other hand, are only rarely found on the external parts of the fish, and although they become attached readily to such places, in the absence of hooks their grasp is insecure, and the usual consequence is that they are all soon brushed off. Being hookless and quite small, they are admirably adapted to lodgment on the gill filaments, among which they may become entangled in great numbers.

Interesting differences of a physiological nature also are correlated with the two structural types, apparently in adaptation to their different parasitic habits.

IMPLANTATION OF THE GLOCHIDIA.

Contact with any part of the fish affords the stimulus which causes the adductor muscle of the glochidium to contract and close the valves. This stimulus is purely a mechanical one, as the same result may be produced by touching with any object. In this way they may be caused to snap shut on a bristle or hair, or on the edge of a piece of paper. Once attached to the fish, however, the glochidium exerts a stimulus upon the epidermal cells of the host which causes them to undergo a rapid proliferation. The stimulus in this case is undoubtedly a chemical one, and its immediate effect is to throw the cells of the epidermis into active mitotic division. The epidermis now grows rapidly over the glochidium, which may become completely embedded in three hours after attachment in the case of the gill parasites. The proliferation of the epidermis of the fins occurs more slowly and in this situation twelve to twentyfour hours are usually required before the glochidia are covered.

After the process of implantation is completed, the glochidia are entirely inclosed within the cellular cyst, where they are nourished by the host until liberated by the rupture of the cyst at the end of the parasitic period. It is during this stage of the development that the metamorphosis occurs and the structure of the glochidium is replaced by that of the mussel.

\section{EXPERIMENTAL INFECTIONS.}

METHOD.

A very large number of experimental infections have been made, and the conditions determining infection have been investigated as far as the material at our disposal has allowed. This study has included not only the behavior of both types of glochidia, their manner and place of attachment, but the reactions of the fish as well. 
Twenty different species of mussels, yielding both hooked and hookless glochidia, have been used for the infections. The majority of these have been species showing the long period of gravidity, although several of the summer breeding species have also been employed. Eighteen species of fishes have been used, and their reactions have been carefully observed, but, as all are not equally favorable for receiving and carrying the parasites, the greater number of infections have been made upon five or six species.

When only a few fishes are to be used at a time, the method which has been employed is quite simple. The brood chambers are excised from the gravid mussels, split open lengthwise, and the ripe glochidia washed and scraped out into dishes of water. The fishes are then placed together with the glochidia in small aquaria, and, if the infection is to be made with gill parasites, the water is agitated by mechanical means, in order to keep the glochidia suspended and thus insure their being taken into the mouth of the fish. When using hooked glochidia for external attachment, however, it is better not to stir them up, as the fishes usually settle down to the bottom of the vessel and, by rubbing their fins among the glochidia, quickly become infected to any desired degree.

When making gill infections, the fishes must be examined at intervals of one or two minutes for the purpose of observing the rapidity with which the glochidia are attaching, and when the degree is reached which experience has shown to be the optimum for the species of fish in question, the exposure is at once discontinued. Usually the gill infections take place very quickly, and in four or five minutes the fishes will have received as many glochidia as they can safely carry, although of course the duration of exposure depends upon the abundance of glochidia in the water. Other things being equal, the fewer glochidia present the more prolonged the exposure must be. Experience has shown that the best results are obtained when the glochidia are used in very "dilute mixtures," for it is difficult to avoid overinfection, if they are at all concentrated. Some species of fishes, however, are less susceptible than others, and a longer exposure is necessary to insure the attachment of an adequate number of glochidia. In certain cases we have had to allow the fishes to remain with the glochidia for from two to three hours, or even longer, in order to obtain a satisfactory degree of infection.

In nearly all of our experiments we have used young fishes, from three to six inches in length, as for many reasons they are more convenient than larger ones.

BEHAVIOR OF FISHES-THEIR SUSCEPTIBILITY AND RESISTANCE.

The fishes when first placed in contact with glochidia give evidence of great irritation, and as soon as the gills begin to be infected they exhibit violent and rapid breathing movements, apparently in the attempt to expel the parasites. 
After a time, however, they become quiet, and when removed from the presence of the glochidia behave normally, except that the more rapid respiratory movements may continue even for days afterwards.

The fishes we have used in our experiments have shown marked differences in their ability to retain the glochidia both on the fins and on the gills, more especially on the latter. They vary even more strikingly with respect to their capacity for withstanding the injurious effects of gill infection, and furthermore some fishes are undoubtedly much more susceptible than others, as the glochidia become attached, especially to the gills, more readily.

Of the fishes which we have had under observation, the following species have proved to be the most satisfactory: rock bass, large and small mouthed black bass, green sunfish, and red-spotted sunfish. All of these species are very susceptible and readily infected with gill parasites, large numbers of which may be carried without apparent injury to the fish. A single individual of any of the above-mentioned fishes, not more than 3 or 4 inches in length, will successfully carry at least $\mathrm{r}, \mathrm{ooO}$ glochidia on its gills to the close of the parasitic period, a number that would speedily kill many other species.

Yellow perch, blue-gill sunfish, and crappie, although quite susceptible, are far less resistent to the injury and quickly succumb to overinfection. Young bullheads are apparently very difficult to infect, and we have not succeeded in causing glochidia to become attached to either their gills or fins in appreciable numbers.

German carp are easily infected on external parts with hooked glochidia, but thus far all efforts to infect this fish with gill parasites have been unsuccessful. The glochidia will attach themselves to the gill filaments, but for some unaccountable reason implantation is imperfect and they soon drop off. Apparently the epidermis of this fish does not react to the stimulus in such a way as to lead to the formation of a permanent cyst.

In still other cases it has been found that failure is due to the fact that, even after complete implantation on either the gills or fins, the walls of the cyst slough away in a day or two and liberate the glochidia. Whether this is caused by unfavorable physiological conditions in the fish or in the glochidia we are unable to say, but there are certain facts that would seem to indicate that such abortive implantations are the result of a physiological immaturity of the glochidia, which therefore fail to call forth the necessary response on the part of the fish's tissues.

\section{DURATION OF THE PARASITIC PERIOD.}

The duration of the parasitic period is very variable. With respect to the glochidia of those species of mussels which remain gravid over winter the duration depends upon the time of year when the infection is made. Fishes 
infected in the late fall and winter will carry the glochidia for from two and a half to nearly four months, while in spring, when the same kind of glochidia are used, the metamorphosis is completed and the young clams liberated in a little less than a month. This great difference in the length of time that the glochidia remain on the fish can not be due primarily to temperature, although this may have some influence, for we have observed the same differences in the laboratory, where the temperature of the water remains practically constant throughout the winter and spring. As the glochidia of the mussels which have the long period of gravidity are not normally discharged until spring and summer, it is quite possible that the fall and winter glochidia are physiologically immature, although capable of causing the formation of the cyst on the fish, and require for this reason a much longer time for the post-embryonic development. Structurally, however, they seem to be identical with those taken from the marsupium in the spring.

In the case of the spring infections the young clams all leave the fish at about the same time, and within a very few days after the first are liberated the last to go have come off. This is not true, however, of the fall and winter infections, for in these cases the setting free of the young mussels may be extended over a period of three or four weeks, or possibly more.

We have no observations on the duration of the parasitic period in the case of the summer-breeding mussels. Although infections have been successfully made with several of these species and kept under observation for ten or twelve days, we have not yet had an opportunity of following the metamorphosis through to the end. The period is, however, undoubtedly short, probably not more than four weeks. Harms (Zoologischer Anzeiger, bd. XxxII, I908) has recently recorded a parasitic period for two European species of Unio, a genus belonging to the group of summer breeders, of twenty-six to twenty-eight days.

\section{POST-LARVAL GROWTH OF MUSSELS.}

No data have been obtained on the rate of growth of fresh-water mussels beyond a short period after the metamorphosis, as we have not succeeded in keeping the young mussels alive in the laboratory for more than four weeks after leaving the fish. The amount of growth during that time was only a fraction of a millimeter. We have made, however, extensive plantings of young mussels which have been allowed to drop off the fishes in ponds and streams where the chances of reclaiming them in the future are very good, and it is hoped that by another year or two some data on the rate of growth will be available. Carefully measured and weighed young mussels of different sizes have also been placed in wire cages and set in ponds and rivers, and it is possible that additional data will be obtained from these experiments. 
INFECTION OF LARGE NUMBERS OF FISH.

In order to test the feasibility of infecting large numbers of fish, which is a prerequisite of artificial propagation, an extensive experiment, in which over 25,000 fish were employed, was made at the substation of the Bureau of Fisheries at La Crosse, Wis., in November, I907. Seven species of fishes and glochidia from four species of Lampsilis were used in the experiment. The fishes, with the exception of the German carp and the bullheads, were successfully infected and retained in the tanks of the station for over two months, when they were liberated in the west channel of the Mississippi River at that place. The experiment completely demonstrated the possibility of making infections successfully on a large scale, and of retaining the fish until near the close of the parasitic period.

In November, I908, a similar experiment was carried out at the station of the Bureau at Manchester, Iowa, where about I2,00o large-mouthed black bass and crappies were infected with the glochidia of several species of Lampsitis. The fish were kept at the station for one month and then placed in the Maquoketa River between two dams. As the species of mussels used in the experiment in all probability do not occur in that stream, the results of the work may be determined if we succeed in reclaiming any of them at a future time.

During the fall and winter of $1908-9$ infected fishes were put into ponds in the neighborhood of Columbia, Mo., where we are absolutely certain that the species of mussels used do not occur, and where there is every reason for the expectation of subsequent reclamation. The latter experiments should yield valuable data on the rate of growth. 


$$
\text { . }
$$






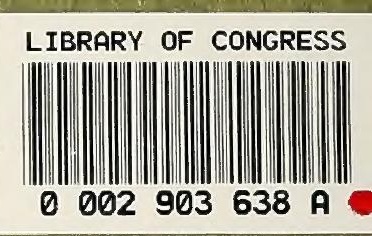

